\title{
A CONEXÃO DOS TEÓRICOS DA PHÝSIS COM O TRÁGICO E A JUSTIÇA
}

\section{THE CONNECTION BETWEEN THE THEORISTS OF PHÝSIS WITH THE TRAGIC AND JUSTICE}

${ }^{1}$ Hilda Helena Soares Bentes

\begin{abstract}
RESUMO
O artigo tem por objetivo a análise da conexão dos teóricos da phýsis com o trágico e a justiça. Propõe-se o estudo desse vínculo como forma de compreensão de uma teorização da essência da Justiça e do trágico, que expresse a verdadeira ideia de Justiça delineada pelos gregos. A investigação pretende resgatar o sentido originário de justiça como conceito fundacional para a Filosofia do Direito. Parte-se de um exame do conceito de phýsis no pensamento pré-socrático, particularmente em Anaximandro, Heráclito e Parmênides, como possibilidade de elaboração dos elementos constitutivos da justiça. A relação da literatura com a justiça revela a importância da interdisciplinaridade como apreensão da condição humana e do desenvolvimento de uma consciência crítica de problemas jusfilosóficos, ainda cruciais para os dilemas contemporâneos.
\end{abstract}

Palavras-chave: Phýsis, Justiça, Trágico, Filosofia do direito, Literatura

\begin{abstract}
The article aims at analyzing the connection between the theorists of phýsis with the tragic and the justice. This link is proposed as a way of theorizing the essence of the Justice and the tragic, that truly expresses the Greek idea of Justice. The investigation intends to recover the original meaning of justice as a theoretical foundation to Philosophy of Law. It starts from the examination of the concept of phýsis in the presocratic thinking, mainly in Anaximander, Heraclitus and Parmenides, as a possibility to conceive the essential elements of justice. The relation between literature and justice reveals the importance of the interdisciplinarity as the apprehension of the human condition and the development of a critical consciousness towards the problems concerning the philosophy of law, still crucial to contemporary dilemmas.
\end{abstract}

Keywords: Phýsis, Justice, Tragic, Philosophy of law, Literature

\footnotetext{
${ }^{1}$ Doutora em Direito pela Pontifícia Universidade Católica de São Paulo - PUC, São Paulo (Brasil) Professora de Direito pela Universidade Católica de Petrópolis - UCP, Rio de Janeiro (Brasil). E-mail: hildabentes@uol.com.br
} 


\section{INTRODUÇÃO}

Pretende-se, neste artigo, estabelecer uma conexão dos teóricos da phýsis com o trágico e a justiça. Propõe-se o estudo desse vínculo como forma de compreensão de uma teorização da essência da Justiça e do trágico, que expresse a verdadeira ideia de Justiça delineada pelos gregos. Trata-se, portanto, de recuperar o sentido originário de Justiça e do arcabouço conceitual que os gregos, como os grandes teóricos da Justiça, nos legaram. O método para alcançar esse objetivo busca estabelecer uma articulação entre a esfera do Direito, especialmente entre o conceito de justiça, e o fenômeno trágico, que constitui uma manifestação artística, jurídica e filosófica de importância vital para a sedimentação dos ideais estéticos e éticos dos gregos.

Os gregos são considerados os mais importantes teóricos da Justiça e do Direito. Resgatar os fundamentos do pensamento jusfilosófico ocidental constitui uma etapa imprescindível para a compreensão total das bases teóricas que alicerçam o nosso edifício jurídico. Começamos a pensar filosoficamente o direito, com os gregos; voltar a eles é recuperar as fundações erodidas pelo tempo e buscar uma reconstrução consistente. É esse móvel que nos faz retornar ao mundo grego e encontrar a razão justificadora de nossa pesquisa, o que explicitamos na segunda parte deste trabalho, intitulado "A correlação do trágico com o os teóricos da phýsis".

Com efeito, a relação Justiça e trágico, e suas implicações jurídicas e literárias, remete-nos ao pensamento dos pré-socráticos, em especial de Anaximandro, Heráclito e Parmênides. Faz-se mister analisar o vocábulo grego phýsis (natureza; processo de nascimento e crescimento), que representa um termo de enorme abrangência conceitual, pois não se esgota na natureza observável, como a tradução tradicional consagrou, mas permite outrossim pensar o ser, o mundo e a Justiça de forma integradora.

$\mathrm{Na}$ primeira parte do desenvolvimento serão apresentados breves apontamentos sobre a democracia na Atenas do século V a.C., pela voz dos sofistas. Na terceira parte será enfatizada a persistência do vocábulo phýsis na configuração do trágico, momento em que a noção de phýsis, teorizada pelos pré-socráticos, será um elemento conceitual importante para o desvelamento do momento trágico e, consequentemente, da justiça, que aflora da imbricação dessas duas manifestações do humano: o sentimento do trágico e da justiça.

A conexão entre a filosofia e literatura, com extensão à filosofia do direito, evidencia a importância da interdisciplinaridade como apreensão do humano e como desenvolvimento de uma consciência crítica dos temas cruciais e problemáticos pertencentes ao direito. O teatro grego 
representa a evolução do pensamento político e jurídico da Atenas do século V a.C., deixando um legado insuperável para a correta intelecção das bases informadoras do pensamento jusfilosófico ocidental.

Parte-se da interrogação de as noções de Justiça e do trágico, derivadas da investigação em torno da phýsis no pensamento inaugural dos pré-socráticos, apresentam elementos estruturais coincidentes que autorizam uma perspectiva interdisciplinar. A hipótese inicial conduz à constatação de que esses dados apresentam uma convergência de propósitos. A finalidade desta pesquisa, por conseguinte, é a articulação da ideia grega de Justiça com a essência do trágico, via uma perquirição do conceito de phýsis, cultivada pelos pré-socráticos. Propõe-se um estudo interdisciplinar que irá extrair do direito e da literatura os elementos teóricos informadores para o desenvolvimento do tema.

\section{1-DESENVOLVIMENTO}

\subsection{BREVES APONTAMENTOS SOBRE A DEMOCRACIA NA ATENAS DO SÉCULO V A.C: A VOZ DOS SOFISTAS}

A onda democrática alastra-se de forma irrefreável em Atenas ao longo do século $\mathrm{V}$ a.C., onde os cidadãos livres, a despeito de sua classe social, disputam um espaço político em todas as instância abertas à manifestação da palavra dialogada, compartilhada, debatida ardorosamente na defesa de opiniões contrastantes. Todos os homens livres da pólis (cidade; cidade-Estado) comungam da isonomía (igualdade de nómos), ou seja, prevalece o império da nómos (norma; convenção) equitativamente partilhada, e da sua inseparável combinatória, a isegoría, que constitui o direito de expressar livremente o pensamento nas assembléias públicas e nos tribunais (MONDOLFO, 1958, p.33). Neste contexto de grandes tensões e polarizações, urge que seja elaborada uma nova pedagogia mais dirigida às finalidades práticas da existência e afinada com as regras da contradita: o adversário deve ser vencido pela arte da palavra. E este papel irá caber aos sofistas que se tornarão os grandes mestres da “sabedoria prática” (BARKER, 1978, p. 66; GUTHRIE, 1987, p. 55), educadores profissionais requisitados pelos ricos para ensinar-lhes os fundamentos da eloquência e da oratória, instrumentos eficientes nas batalhas travadas nos tribunais e nas arenas políticas, como expõe Górgias sobre o poder de convencimento da palavra:

GÓR. Ao poder de, pela palavra, convencer os juízes no tribunal, os senadores no conselho, os eclesiastas na assembléia e em todo outro ajuntamento onde se congreguem cidadãos. De fato, com esse condão, escravo teu será o médico; escravo teu, o mestre da ginástica e, como se 
verá, o tal financista estará produzindo riqueza não para si, mas para ti, que tens o dom de falar e convencer a massa. (PLATÃO, 1989, 452, p. 58-9)

Seria errôneo considerar os sofistas professores que se destacam simplesmente por exercerem atividades lucrativas; as reprovações provenientes em especial de Platão, no Górgias, e de Aristóteles, na Ética a Nicômaco, não fazem jus à tarefa por vezes desinteressada desenvolvida pelos grandes mestres da sofística e pela invejável erudição que muitos deles ostentam, o que lhes permite angariar uma invulgar dignidade no pensamento filosófico e uma inegável importância na condução dos assuntos políticos atenienses (PLATÃO, 1989, 520, c,d,e, p. 181-182; ARISTÓTELES, 1973, 1164, p. 25). Poder-se-ia qualificar os sofistas como educadores que aspiram a granjear fama e poder através do contato direto com os cidadãos concitando-os a aprimorarem as suas capacidades intelectivas, ou, como bem coloca Windelband, "a filosofia saiu da escola e se apresentou no mercado. Esses professores públicos da ciência são os sofistas.” (1955, p. 113).

Malgrado depreciações negativas que amiúde fazem denegrir a imagem dos sofistas, é consensual que os seus ensinamentos produzem um inequívoco elogio do Homem, centro de investigação que passa a ocupar a atenção dos filósofos. $\mathrm{O}$ afloramento da questão antropológica coincide com a consolidação das instituições democráticas e com a criação de um espaço artístico - o teatro - onde o foco principal incidirá na ação e na consciência do homem trágico, apto a protagonizar todas as porfias e os desafios inerentes à condição humana (BARKER, 1978, p. 59 e 66; VERNANT, 1976, p. 298).

De fato, o homem será o herói de uma história que irá enaltecer todas as virtudes e todos os vícios, mas que assume o papel principal em razão da sua irresistível inclinação para vencer toda limitação, como proclama o coro em Antígone: "Muitos milagres há, mas o mais portentoso é o homem." (SÓFOCLES, 1997, 334, p. 58) ${ }^{1}$. Sobretudo a glorificação do homem está intimamente ligada à sua habilidade de usar as palavras, porquanto elas representam as armas ora empregadas para persuadir o opositor sem apelar para recursos violentos e irracionais. Nesse sentido, vale transcrever o fragmento de Górgias, intitulado Elogio de Helena, passagem significativa que retrata a profunda reviravolta que a exaltação da palavra provoca na cultura humana:

[...] A palavra é uma grande dominadora que, com pequeníssimo e sumamente invisível corpo, realiza obras diviníssimas, pois pode fazer cessar o mêdo e tirar as dores, infundir a alegria e inspirar a piedade. [...] $\mathrm{O}$ discurso, persuadindo a alma, obriga-a, convencida, a ter fé nas palavras e a consentir nos fatos. [...] A persuasão, unida à palavra, impressiona a alma

\footnotetext{
${ }^{1}$ Cf. sobre esta passagem de Antígone associada ao movimento sofístico, ZELLER (1980, p. 91).
} 
como quer, [...] O poder do discurso com respeito à disposição da alma é idêntico ao dos remédios em relação à natureza do corpo. [...]. (Apud MONDOLFO, 1971, p. 139) ${ }^{2}$

Os sofistas implantam uma filosofia centrada no problema antropológico, na ênfase na humanidade e na civilização. Por esse motivo, vários historiadores dividem a filosofia grega em três períodos: o período cosmológico (600-450 a.C.), correspondente ao nascimento da filosofia representada pelos pré-socráticos; o período antropológico (450-400 a.C.), equivalente a segunda metade do século quinto e dominado pelas ideias sofísticas; e o período sistemático (400-322 a.C.), preenchido pelo aperfeiçoamento dos três grandes sistemas da filosofia, elaborados por Demócrito, Platão e Aristóteles (WINDELBAND, 1958, p. 119). Os sofistas opõem-se à filosofia da natureza pelo deslocamento de questões filosóficas cruciais: anteriormente, o pensamento especulativo havia se voltado para a descoberta de um substrato único e imutável que rege o cosmo, utilizando um método essencialmente dedutivo de investigação; a invenção dos sofistas reside na recusa em encontrar um princípio absoluto e permanente que comanda o universo, mas em explorar a realidade cambiante via uma perquirição empírico-indutiva (BARKER, 1978, p. 63-65; ZELLER, 1980, p. 76-77).

É importante realçar que, inobstante as divergências que separam os sofistas dos filósofos da natureza, ou seja, dos pré-socráticos, existe um elo que os aproxima: os sofistas são originários das colônias gregas da Jônia e da Magna Grécia. Este fato explica o profundo conhecimento acerca de problemas filosóficos fundamentais que eles exibem com desenvoltura como, por exemplo, as discussões sobre o Ser e o Devir, sobre a unicidade e a multiplicidade, sobre alétheia (verdade) e dóxa (opinião), sobre o ser e o parecer, além do domínio da dialética, da lógica e da retórica inventadas pelos pré-socráticos (BARKER, 1978, p. 66). Portanto, imbuídos do caráter intelectual da filosofia antecedente, porém pregando um sentido mais utilitário aos seus ensinamentos, os sofistas transformam-se em professores itinerantes, portadores da antiga sophía (sabedoria), que unificava ação e contemplação. Na Atenas do século quinto são estrangeiros, disseminando ideias extraordinárias e instigantes,

\footnotetext{
${ }^{2}$ Tradução do fragmento de Górgia em italiano, denominado Elogio di Elena, 8-14, por Maria Timpanaro Cardini, na compilação I sofisti: frammenti e testimonianze (1923, p. 57-9), in verbis: “[...] la parola è un gran dominatore, che con piccolissimo corpo e invisibilissimo, divinissime cose sa compiere; riesce infatti e a calmar la paura, e a eliminare il dolore, e a suscitare la gioia, e a inspirar la pietà. [...] Infatti un discorso che abbia persuaso una mente, costringe la mente che ha persuaso, e a credere nei detti, e a consentire nei fatti. [...] E che la persuasione, congiunta con la parola, riesca a dare all'anima l'impronta che vuole, [...] C'è tra la potenza della parola e l'ufficio dell'anima lo stesso rapporto che tra l'ufficio dei farmachi e la natura del corpo. [...]". Registre-se que Protarco, no Filebo (1974, 58,a, p. 169), de Platão, comenta a arte da palavra desenvolvida por Górgias: "Eu, Sócrates, do meu lado, ouvi muitas vezes Górgias declarar que a arte de persuadir ultrapassa, de muito, em importância, as demais artes, pois que tudo se lhe submete, não por violência, mas de bom grado, por ser ela a melhor das artes. [...]".
} 
que irão fermentar as obras artísticas e políticas de valor excepcional. A palavra dos sofistas que insculpirá o novo Homem é feita da pregnância do pensamento dos pré-socráticos.

Os sofistas são transmissores de toda uma rica herança cultural. Não são meros repetidores, pois postulam posições políticas e filosóficas que os afastam dos seus célebres antecedentes. Contrariamente aos principais representantes do pensar pré-socrático, a sofística caracteriza-se por privilegiar a lógica da ambiguidade, construindo pares antitéticos que não se excluem e que lutam para defender uma determinada tese por meio de artifícios argumentativos. Esses discursos contrapostos são conhecidos como dissoí lógoi; é a vitória da palavra numa cultura em que "o sofista e o retórico são ambos técnicos do lógos." (DETIENNE, 1988, p. 62). Abandona-se a pretensão filosófica de alcançar a plenitude da alétheia, palmilhada pelos Mestres da Verdade; busca-se um caminho humanamente trilhável: o mundo da contingência, da transitoriedade, das contradições, aponta para a dóxa, forma de conhecimento apropriado por espelhar a mutabilidade do real (DETIENNE, 1988, p. 60-63).

\subsection{A CORRELAÇÃO DO TRÁGICO COM O OS TEÓRICOS DA PHÝSIS}

Os elementos trazidos pelo pensamento sofístico interagem na composição dramática. Indaga-se se o cerne dos questionamentos dos pré-socráticos estaria muito distante da obra realizada pelos trágicos? Ou o debate promovido pelos sofistas traz à tona questões essenciais acerca da natureza humana formuladas pelos primeiros filósofos, material que seria reelaborado artisticamente pelos tragediógrafos? Certamente que a projeção da sofística no palco ateniense do século V a.C. não se limita aos recursos retóricos empregados na estrutura dialogal das peças; mais penetrante afigura-se o enfoque dado à problemática do homem e ao fundamento filosófico que confere dimensão universal às tragédias. Na verdade, o caráter reflexivo da tragédia grega provém do intenso intercâmbio de ideias que se desencadeia em Atenas, fruto da expansão da democracia e da interlocução fecunda com os sofistas das colônias estrangeiras.

Entretanto, vários autores têm assinalado a correspondência entre o pensamento dos pré-socráticos e a natureza do trágico. $\mathrm{Na}$ verdade, há uma continuidade de questões filosóficas discutidas pelos pré-socráticos que contêm elementos reveladores da essência do trágico. Nietzsche tenta reabilitar os pré-socráticos analisando-os pelo prisma trágico, vale dizer, os primeiros filósofos seriam os felizes intérpretes da "união fraterna de Diónisos e Apolo" (1988, p. 40), conforme descreve Eugen Fink, ainda não subjugados pela poderosa dialética de Sócrates, que decreta a separação dos princípios determinantes da concepção 
trágica de mundo e, consequentemente, a morte da tragédia. Com o socratismo a visão teorética sai vitoriosa, abandonando-se a concepção unitária e englobante da phýsis (o processo de nascimento e desenvolvimento das coisas) (NIETZSCHE, 1992, p. 87-90) ${ }^{3}$.

Renuncia-se às contradições inerentes à vida que constituem, segundo o olhar percuciente de Heráclito (BORNHEIM, 1991), tensões harmonicamente resolvidas. E os grandes trágicos do século quinto sabem traduzir com genialidade toda a complexidade da phýsis esboçada pelos pré-socráticos, e conjugar com arte o processo imitativo que faz brotar o verdadeiro sentido da natureza das coisas. Ou seja, arte e natureza não se opõem; ao contrário, estabelece-se uma relação dinâmica entre elas, pois, como Hölderlin afirma, em Fundamento para Empédocles, "na pureza da vida, arte e natureza só podem se contrapor harmonicamente. A arte é florescência, a plenitude da natureza." (1994, p. 82)

A famosa sentença de Anaximandro que, combinando procedimentos cósmicos e humanos com a mesma terminologia associada à díke (Justiça), revela a força poética alcançada pela técnica da palavra deixando transluzir todo o vigor da phýsis: "Mas, donde provêm todos os entes, aí se corrompem também, por fôrça da Necessidade; pois devem expiar reciprocamente a culpa da sua injustiça, segundo a ordem do Tempo [ou: segundo a sentença proferida pelo Tempo]”. (SOUSA, 1954, v. IV, fascículo 1, p. 104). Além das interpretações éticas e jurídicas, Heidegger propõe uma análise que busca decifrar o verdadeiro sentido do Ser exposto à multiplicidade, que luta por retornar ao Uno primordial. Em outros termos: a grande injustiça que o homem pratica é permanecer obstinado na corrente irresistível da individuação, persistindo na aparência, sem voltar à essência unificadora. A existência para Anaximandro apresenta uma forte coloração trágica, porquanto o homem, ser exilado, carrega uma culpa a ser expiada pela injustiça da separação (BORNHEIM, 1969, p. 7677; BRUN, 1991, p. 22 e 52; HEIDEGGER, 1987, p. 187).

Por conseguinte, o indivíduo vive num estado de transgressão original, conceito que irá inspirar sem dúvida a temática da tragédia. Com efeito, a falta trágica, ou hamartía, consiste no cometimento de algum erro violador dos princípios da justiça. O homem trágico assume o papel de ser transgressor que aspira à recomposição da situação de equilíbrio, perturbada pelos efeitos danosos da sua ação desmedida. Importa compreender - e aí está o cerne do

\footnotetext{
${ }^{3}$ Sobre a posição nietzscheana em oposição ao socratismo, ver FINK (1988, p. 20 e 40), e DELEUZE ([s.d.], p. 23), em que expõe com precisão: “[...] Sócrates é o primeiro génio da decadência: opõe a ideia à vida, julga a vida pela ideia, postula a vida como algo que deve ser julgado, justificado, resgatado pela ideia. O que ele nos pede é que sintamos que a vida, esmagada sob o peso do negativo, é indigna de ser desejada por si mesma, experienciada por si mesma: Sócrates é o ‘homem teórico', o único verdadeiro contrário do homem trágico.”

${ }^{4} \mathrm{Na}$ mesma obra, consulte-se o artigo de Françoise Dastur, explicativo sobre a relação da arte com a natureza à luz da colocação de Hölderlin (p. 156).
} 
problema - o fundamento que preside a origem e a destruição das coisas, que determina qual a medida do homem e qual o parâmetro aferidor da justiça e da injustiça. Observa-se que o fragmento de Anaximandro, conquanto brevíssimo, encerra questionamentos que permanecem dramaticamente irrespondíveis na "ordem do Tempo". Jean Brun indaga a condição trágica do homem, ser derrelito dividido entre a existência culpada e a aspiração à totalidade:

O homem é essencialmente o ser exposto; é exposto na medida em que é presença saída do abandono do Uno. É exposto na medida em que a sua condição é trágica. Diz Heráclito: 'É difícil lutar contra o seu coração, porque o que deseja compra-se à custa da alma'. (fgt. 85) Convirá entender, simplesmente, por isso que a paixão perde a nossa alma, o que não passaria de lugar-comum, ou, antes, que o desejo que nos fala ao coração é o de nos arrancar à individualidade a que preside a nossa alma e à qual se encontra ligada? (1991, p. 53)

E Heráclito é o pensador pré-socrático mais aclamado como trágico, porém sua complexidade exige um exame cuidadoso para se desviar de equívocos. Decerto que ao afirmar o devir, Heráclito absolve-o de toda culpabilidade e resgata uma integridade que permite ao homem procurar "a justificação do ser" (DELEUZE, [s.d.], p. 39) ${ }^{5}$, ou, como declara o Efésio em sentença famosa (fragmento 101): "Indaguei-me a mim próprio." (SOUSA, 1954, v. IV, fascículo 2, p.316). Mas o pensamento heraclitiano não se define como trágico apenas por rejubilar-se na embriaguez do devir; o dilaceramento radica na busca do Lógos (palavra, razão), pensamento comum capaz de estabelecer as articulações necessárias para que o homem dissipe as máscaras enganadoras do real, as falsas aparências, conforme atesta Heráclito no fragmento 17: "Muitos não compreendem o que se lhes depara, nem o reconhecem, depois de o aprenderem; mas imaginam que sim." (SOUSA, 1954, v. IV, fascículo 2, p. 301) ${ }^{6}$. Todavia, o lógos normalmente escapa aos homens, que vivem circunscritos às suas particularidades (fragmento 2) e renitentes a qualquer abertura propícia

\footnotetext{
${ }^{5}$ A leitura de Deleuze sobre a obra de Nietzsche aponta para o reconhecimento de que "Heráclito é o pensador trágico" (p. 38) e que "não viu qualquer castigo do múltiplo, qualquer expiação do devir, nenhuma culpabilidade da existência. Não viu nada de negativo no devir, viu o oposto: a dupla afirmação do devir e do ser do devir, em suma, a justificação do ser. [...]” (p. 39). Contudo, a análise de Deleuze chama a atenção para o fato de que o pensamento de Heráclito não exclui as noções de castigo e culpabilidade, como se poderia deduzir da interpretação de Nietzsche.

${ }^{6}$ Convém transcrever o mesmo fragmento na tradução José Cavalcante de Souza (1996, p. 89), pela ênfase dada ao verbo parecer, que expressa com nitidez a crítica de Heráclito aos indivíduos que vivem na aparência, sem procurar a verdadeira essência das coisas: "Muitos não percebem tais coisas, todos os que as encontram, nem quando ensinados conhecem, mas a si próprios lhes parece (que as conhecem e percebem).”
} 
ao acolhimento da palavra reveladora, pois "não sabem escutar nem falar." (SOUSA, 1954, v. IV, fascículo 2, p. 301) ${ }^{7}$.

A doutrina heraclitiana ganha maior dramaticidade porquanto mesmo os que estão em estado de vigília (fragmentos 1 e 89), buscando a unidade presente no múltiplo, empreendem uma jornada reflexiva sem a certeza de contemplarem a verdade. Heráclito (fragmento 18) adverte que "quem não espera, o inesperado não achará; que esse é inexplorável e inacessível." (SOUSA, 1954, v. IV, fascículo 2, p. 301). Donde subsiste a nota trágica, conflitiva, que transforma o homem num ser em permanente tensão, cortejando uma transcendência inatingível ou "confinando-se à sua própria imanência" (BORNHEIM, 1969, p. 80). O pensamento de Heráclito enraíza-se essencialmente no trágico na medida em que, na síntese de Jean Brun, “o Logos é, pois, simultânea e paradoxalmente, um Sentido que nos transcende e uma significação que nos é imanente. O Logos situa-se no coração da brecha pela qual o homem é dilacerado entre o Ser perdido e a existência que o constitui; a sua condição só pode ser trágica." (1991, p. 43-44).

O pensamento de Heráclito é igualmente trágico por formular a guerra dos opostos, os quais travam um combate incessante para preservar o equilíbrio necessário à manutenção da ordem cósmica. Exalta a guerra como o princípio norteador da natureza humana, como regente do universo, pois "Prélio é o pai de todas as coisas, de todas o rei" (SOUSA, 1954, v. IV, fascículo 2, p. 307), capaz de extrair a mais bela harmonia do entrelaçamento das notas dissonantes, "qual a do arco e da lira" (SOUSA, 1954, v. IV, fascículo 2, p. 306). Heráclito observa com agudeza a inexpugnável polaridade que comanda o mundo físico e humano, cenário de espetaculares contradições que lutam para atingir o acordo invisível, somente acessível àqueles que, escutando o Lógos, articulam as conexões e reconhecem sabiamente que "tudo é um" (SOUSA, 1954, v. IV, fascículo 2, p. 306) ${ }^{8}$. Com efeito, a teoria dos contrários serve de inspiração para a configuração dos elementos estruturais da arte trágica, razão por que Heráclito é considerado o filósofo trágico por excelência. A ação trágica sempre coloca o herói em tensão permanente com o sentido da ordem, ou seja, o conflito está radicado nesses dois pólos fundamentais (BORNHEIM, 1969). René Girard define o debate trágico como "uma substituição da palavra pela espada no combate singular" (1990, p. 63), na

\footnotetext{
${ }^{7} \mathrm{O}$ fragmento 2 explica com clareza a censura de Heráclito à obstinação dos homens em não seguir o lógos e mergulhar na sua própria individualidade: "Por isso convem ( sic) seguir o comum. Mas ainda que o LOGOS seja comum a todos os viventes, vive a multidão como se tivesse pensamento próprio." (SOUSA, 1954, v. IV, fascículo 2, p. 299).

${ }^{8}$ Trecho do fragmento 50, na tradução de Eudoro de Sousa, que assim se completa: "Se escutastes, não a mim, mas ao LOGOS, sábio é reconhecer que tudo é um.”
} 
medida em que as personagens estão simetricamente opostas em posição de combate para defender suas crenças, convicções, paixões.

A filosofia heraclitiana converte-se, de acordo com Jean Brun, "numa filosofia da dilaceração" (1991, p. 45), em que o homem, mesmo perseguindo a harmonia invisível, defronta-se com um espetáculo de oposições violentas, pois está situado no epicentro de uma insolubilidade asfixiante. Entretanto, Heráclito não se fixa na superficialidade das aparências: o seu intuito é deixar transparecer a justiça intrínseca à constituição das coisas; condena, portanto, os efeitos devastadores da hýbris (excesso, soberba, insolência), que provoca males mais funestos que um incêndio, e exorta, com veemência, o homem a procurar a medida definidora da sua existência, vez que "a todos os homens foi dado o conhecerem-se a si mesmos e o sãmente pensar." (fragmento 116) (SOUSA, 1954, v. IV, fascículo 2, p. 317) ${ }^{9}$ Poder-se-ia concluir que a essência do trágico localiza-se precisamente no fato de o homem negar uma medida transcendente - a "lei divina" (fragmento 114) (SOUSA, 1954, v. IV, fascículo 2, p. 317) de Heráclito - e perseverar numa singularidade desafiadora aos deuses e encobridora da sua real natureza. Gerd Bornheim reconhece a tragédia grega como caudatária do pensamento pré-socrático:

\begin{abstract}
O próprio de quem vive entregue ao mundo da aparência é fazer do homem a medida do real, fazendo com que êle recuse uma medida que o transcende. Nessa recusa da transcendência radica o pseudos, a injustiça, a culpa. $\mathrm{O}$ homem se torna - enquanto vive, como dissemos, a teimosia de sua particularidade - princípio da lei, e rejeita um princípio (arke) que transcenda a sua particularidade. $\mathrm{O}$ nómos Theios, a lei divina, de que fala Heráclito é preterida. $\mathrm{O}$ indivíduo passa a ser, assim, prêsa da aparência ou de uma medida aparente, porque sua, particular; êle incide em hybris, ou desmedida, o oposto da existência que encontra a sua medida na 'lei divina', e que por isso é justa. $O$ herói adota, de um modo consciente ou não, uma espécie de faux semblant; êle age como se tôda medida que o transcende tivesse perdido sentido. E êle e trágico precisamente porque esta sua posição se revela mentira. Topamos, pois, com uma injustiça que obriga ao reconhecimento da justiça.(1969, p. 79-80; grifos nossos)
\end{abstract}

Cuida-se, portanto, de descobrir a verdadeira essência das coisas, de apreender a unidade não visível, nuclearmente antitética, que deve habitar as profundezas do Ser e do lógos. Heráclito afirma, no fragmento 112, que cabe ao sábio ser o portador da verdade, auscultando a natureza: "Sabedoria é a suprema virtude, e saber consiste em dizer a verdade e agir em conformidade com a natureza, obedecendo-lhe.” (SOUSA, 1954, v. IV, fascículo 2, p.

\footnotetext{
${ }^{9}$ Deve-se citar o fragmento 43, na tradução de Eudoro de Sousa (SOUSA, 1954, v. IV, fascículo 2, p. 305), sobre os efeitos calamitosos da hýbris: "mais importa extinguir a soberba que o incêndio." Atente-se que, em Bornheim, hýbris é traduzida por "desmedida": "Melhor apagar a desmedida que um incêndio." (1991, p. 38).
} 
317). Esta frase exprime a concepção grega de phýsis, intrinsecamente ligada à irrupção da verdade e da aparência na medida em que, consoante Heidegger,

[...] o Ser se Essencializa como physis. O vigor imperante, que surge e brota, é aparecer. Êsse apresenta. Tudo isso implica: o Ser, aparecer, deixa sair da dimensão do velado, do coberto. Enquanto o ente é, como tal, instaura-se e se instala na dimensão do re-velado, do des-coberto. [...]" (1987, p. 129).

A filosofia heraclitiana conduz a um "aclaramento metafísico" (FINK, 1988, p. 18) ${ }^{10}$, que converge para a visão parmenideana do Ser, para o jogo de luz e obscuridade que se instala na caminhada do jovem que deseja ser sophós (sábio). Phýsis e lógos estão intimamente entrelaçados no poema de Parmênides para deixar manifestar a plenitude do Ser bem redondo, equilibrado, firmemente configurado para contemplar a verdade (SOUZA, 1996) ${ }^{11}$. O sábio deve, por conseguinte, adquirir uma clarividência que o faça discernir o ser da aparência, o verdadeiro do falso, dissolvendo as camadas opacas que impedem o total desvelamento, pois, tal qual as filhas do Sol, forçoso é retirar "com as mãos os véus." (SOUZA, 1996, p. 121). Constitui, de fato, uma experiência singular dos primeiros pensadores estabelecer uma relação de reciprocidade entre o Ser e a aparência, entendida esta com toda a densidade que o vocábulo evoca, na proporção de que dóxa significa originalmente opinião, mas igualmente aparência, fama, glória. Contudo, toda esta problemática encontra, no século V a.C., um meio de expressão privilegiado: o jogo teatral.

\subsection{O FLORESCIMENTO DO TEATRO: A PRESENÇA DA PHÝSIS NA CENA TRÁGICA}

O teatro tem por vocação criar um olhar concentrado para levar o homem a uma total imersão na sua interioridade, deixando que sua phýsis aflore com vigor e desencadeie um processo irreversível de descoberta da verdade. Ocorre, como afirma sugestivamente Karl Reinhardt, "um assalto da verdade contra o aparato da aparência" (1994, p. 144) $)^{12}$; Édipo (1991), por exemplo, obsedado pela paixão de buscar a verdade, é arrastado até o total

\footnotetext{
${ }^{10} \mathrm{O}$ autor analisa a filosofia de Nietzsche, intérprete da filosofia trágica dos pensadores pré-socráticos, como possibilidade de decifrar o mundo através de uma visão trágica.

${ }_{11}^{1} \mathrm{Na}$ tradução de José Cavalcante de Souza, o poema de Parmênides, através das palavras da deusa, expõe os atributos que deve possuir o ser pleno.

${ }^{12} \mathrm{Na}$ tradução francesa de Emmanuel Martineau, assim se apresenta: “[...] l'assaut de la vérité contre l'appareil de l'apparence [...]". Consultem-se os seguintes autores sobre a temática do ser e parecer mesclados na ação trágica: FINK, (1988, p. 21); HEIDEGGER, 1987, p. 133-134), em que faz menção especial ao magistral trabalho interpretativo de Reinhardt, por ser ele um intérprete da concepção grega do ser; SNELL, 1965, p. 166167).
} 
desnudamento, porquanto ele próprio, voluntariamente, pede que "irrompa o que tiver de vir" (1991, 1271, p. 76). Com efeito, Édipo precipita-se impetuosamente na busca da verdade mas não suporta a luminosidade do sol: recolhe-se na visão interior que ele havia desdenhado em Tirésias $^{13}$. A tragédia, portanto, percorre o itinerário proposto por Parmênides na medida em que ela visa precipuamente a desvendar a trilha do Ser e da Verdade, renunciando a seguir a via da não-existência, ou, na correta elocução de Bornheim:

[...] Na tragédia, deparamos com a existência humana entregue ao conflito que deriva do entrelaçamento do ser e da aparência. [...] O desenvolvimento da ação trágica consistiria na progressiva descoberta da verdade - verdade no sentido de aletheia: manifestar-se, descobrir-se, 'desconder-se'. Não é a essência do herói, restrita a sua individualidade, que vem à tona, mas a aparência na qual está submerso: a aparência é des-coberta, e nela mostrase a própria physis do herói. [...]. (1965, p. 78-79, grifos nossos).

Todo este manancial de ideias férteis cultivadas pelos pré-socráticos faz parte do repertório cultural dos sofistas que, mestres errantes, expõem intensamente os seus ensinamentos ao público. Como já mencionado, os sofistas, diferentemente dos filósofos da natureza, não acreditam numa unidade original que comanda o universo, capaz de servir de fundamento absoluto de validade universal; ao revés, a sofística instala-se na mutabilidade do devir, observando que as instituições humanas são caracterizadas por uma enorme variabilidade. Donde, conclui-se que a doutrina dos sofistas irá instituir novas coordenadas: o enfoque não será mais físico ou "metafísico"; e, ao invés de princípios invariáveis, o conhecimento cairá na mais profunda relatividade. Desponta um novo homem, criador das suas leis e convenções, perspectiva que irá desembocar na debatida antítese entre lei e natureza. Sir Ernest Barker comenta o nascimento do estudo especulativo voltado para a ética

e a política:

[...] E não parecia haver qualquer coisa que fosse 'a mesma e comum a toda a Humanidade'. Todo isto não podia ser produto da Natureza, mas sim do Homem. A própria Lei eram (sic) uma convenção e o Estado se baseava num contrato. Assim, enquanto o estudo da física tinha avançado a concepção de um substrato único, subjacente a toda matéria, o estudo antropológico do universo moral mostrava a variedade infinita das instituições. Invertia-se a relação de outrora: a Natureza tinha uma só Lei, enquanto que a ordem humana era vária. A física se opunha à antropologia; e esta oposição

\footnotetext{
${ }^{13}$ A tragédia Édipo Rei apresenta uma rica imagística em torno da oposição entre Luz x Noite, elaborada para simbolizar a busca pela contemplação da verdade. Por ironia, Édipo, no início da peça, invoca Apolo, deus da luz, para auxiliá-lo na descoberta do culpado do assassinato de Laio (1991,101-102, p. 24); posteriormente travase um violento duelo entre Édipo e o cego Tirésias, também calcado na dicotomia luz x noite (1991, 448 a 453 , p. 38); por fim, ao ser revelada toda a verdade, Édipo exclama pateticamente: "Ai de mim! Ai de mim! As dúvidas desfazem-se!/ Ah! Luz do sol. Queiram os deuses que esta seja/ a derradeira vez que te contemplo! (1991, 1386 a 1388, p. 82); no final da tragédia, Édipo, abatido pela "nuvem negra de trevas" (1991, 1556, p. 87) que tombou sobre o seu destino, atribui a Apolo a autoria pelas desventuras que tem de suportar (1991, 15761577, p. 88). Cf. na mesma direção, REINHARDT (1994, p. 150-151).
} 
resultava na antítese da lei natural e do costume. Foi assim, em parte, que se estabeleceu a antítese da ciência natural e do estudo das instituições. (1978, p. 64).

Cumpre averiguar, nesta etapa, o sentido de Justiça que lhe emprestam os présocráticos. Com referência a Anaximandro, importa assinalar que o seu fragmento revela uma inequívoca transposição, para o plano cósmico, da experiência jurídica travada nos tribunais. Segundo Werner Jaeger (1989, p. 138-139), a analogia de Anaximandro confere ao conceito de legalidade uma significação transcendental, vale dizer, díke exprime um princípio universal, responsável pela indefectível recomposição de todas as injustiças perpetradas na ordem cósmica ou humana. Ademais, a evocação do pensamento de Sólon reforça a ideia de inexorabilidade do Tempo, de uma Justiça natural, que preserva o equilíbrio do mundo ao punir todo o excesso indevido, ou seja, a pleonexía (desejo de possuir sempre mais), e os efeitos desestabilizadores da harmonia perfeita (BARKER, 1978, p. 63; VERNANT, 1977, p.

59). Em contrapartida, para Eric Havelock a sentença de Anaximandro é uma metáfora derivada dos procedimentos legais, em que Justiça significa ordenação e penalidade baseada em regras de reciprocidade previamente estabelecidas (1978, p. 263-264) ${ }^{14}$.

Heráclito torna mais explícito o conceito de Justiça entendida como reciprocidade ao declarar que "importa saber que o Prélio é comum, e que a justiça é querela" (Fragmento 80) (SOUSA, 1954, v. IV, fascículo 2, p. 312), unificando a guerra, a praça pública e os tribunais, para retratar a natureza conflitual, agonística, que prevalece nas relações humanas. O conflito, destarte, constitui o elemento integrador das diversas ordens sociais na medida em que os constantes combates entre os homens e os povos obrigam a institucionalização de procedimentos reguladores das retribuições em face das transgressões aos ditames da Justiça (HAVELOCK, p. 1978, p. 265). A teoria heraclitiana de Justiça reelabora a personificação da deusa Díke, já esboçada em Hesíodo (1996), para simbolizar a regência de uma medida cósmica e universal, pois "Hélio não transporá seus limites: senão, as Erínias que a Diké assistem, irão encontrá-lo.” (Fragmento 94) (SOUSA, 1954, v. IV, fascículo 2, p. 314). A Díke distribuidora dos castigos constitui uma força implacável na perseguição da desmedida e da injustiça.

Sublinhe-se que a medida da Justiça, na visão de Heráclito, está em estreita conexão com o Lógos divino. Em consequência, a "lei divina" converte-se na lei fundamental para conferir validade às leis humanas que "se nutrem de uma só, divina, que tudo governa, podendo quanto quer, em tudo bastando, tudo excedendo." (Fragmento 114) (SOUSA, 1954,

\footnotetext{
${ }^{14}$ No mesmo sentido pronuncia-se Michael Gagarin, no artigo Dike in Archaic Greek Thought, (1974, p. 195).
} 
v. IV, fascículo 2, p. 317; GAGARIN, 1974, p. 195). A Díke personificada de Heráclito adquire maior transparência ao ser contraposta às injustiças, como se observa no fragmento 23: "O nome Diké (Justiça) seria ignorado, se não fossem essas coisas [as injustiças?]." (SOUSA, 1954, v. IV, fascículo 2, p. 302). Esta contradição implica que o nome da Justiça, para ser apreendido conceptualmente, deve atravessar as vias da afirmação e da negação a fim de que a descoberta da ideia de Justiça seja captada de forma límpida e incontroversa.

Este parece ter sido o caminho de Parmênides que, embora não tendo definido a natureza de Díke no seu poema, certamente a considera uma inquestionável força divina, capaz de servir de parâmetro para guiar os passos do filósofo. A medida está, portanto, na esfera solar, divina, representada por Díke e Thémis, porquanto a deusa recepciona o jovem com as seguintes palavras: "Pois não foi mau destino que te mandou perlustrar/ esta via (pois ela está fora da senda dos homens), mas lei divina e justiça;" (SOUZA, 1996, p. 122; GAGARIN, 1974, p. 195) cuida-se, assim, de instituir princípios filosóficos que possibilitem o homem encontrar o conhecimento verdadeiro, unificando leis racionais que se inscrevem no humano e que o transcendam. Parmênides explicita a via do Ser, secundado por Díke, que constrói as bases lógicas do pensamento, mas que, de acordo com Eric Havelock, não permitem ainda uma definição formal de Justiça (1978, p. 268-271).

Importa ressaltar que, no contexto do século V a.C. em Atenas, phýsis ainda faz parte da terminologia adotada pelos sofistas, porém agora empregada com uma forte carga contestatória para pôr em evidência as deficiências das leis convencionadas pelos homens. Em outras palavras: não se trata mais de provar a existência de uma Lei cósmica universal capaz de servir de padrão único para o julgamento das ações humanas; a phýsis transforma-se num poderoso recurso argumentativo, hábil em denunciar as usurpações causadas pelo arbítrio do homem. E parece ter sido Arquelau, considerado o último filósofo da natureza, e, segundo a doxografia de Diôgenes Laêrtios, discípulo de Anaxágoras e professor de Sócrates, quem primeiro estabelece a distinção entre phýsis e nómos ao ensinar que "o justo e o torpe não existem por natureza, e sim por convenção" (1977, livro II, capítulo 4, 16, p. 51). Cria-se, assim, uma antítese irreconciliável de enorme repercussão na história do Direito e que aparece, igualmente, de forma aporética em outras manifestações da vida humana, como na literatura e na política. Aristóteles, na Arte Retórica, situa bem a problemática e realça a força das duas posições: as leis conforme a natureza contrapostas às leis escritas:

3. Falemos primeiro das leis, para dizer como se deve usar delas, consoante se aconselha ou desaconselha, consoante se é acusador ou demandado. 4. É obvio que, se a lei escrita é contrária à nossa causa, será necessário recorrer à lei comum e às sugestões da eqüidade, por estas serem mais justas. 5. 
Convém saber que 'julgar segundo sua consciência', não é recorrer às leis escritas, em todo seu rigor; 6. que, além disso, o eqüitativo é permanente e imutável, como a lei comum - por ser conforme à natureza, - ao passo que as leis escritas mudam freqüentemente. Daí as palavras que se lêem na Antígona de Sófocles; Antígona defende-se e afirma que, enterrando Polinice, infringiu a lei de Creonte, mas não a lei não escrita. ([s.d.], Livro I, capítulo XV, II, 3-6, p. 86) ${ }^{15}$

E esta aporia, como Aristóteles aponta, encontrará em Antígone a sua configuração artística e jurídica mais perfeita.

\section{CONSIDERAÇÕES FINAIS}

O objetivo precípuo deste artigo, denominado “A conexão dos teóricos da phýsis com o trágico e a justiça”, resgata o pensamento dos pré-socráticos acerca do conceito de phýsis e visa a articulá-lo com as manifestações do trágico e da justiça, que surgem de forma resplandecente em Atenas no século V a. C. Convém sublinhar que essa ligação é extremamente reveladora para a compreensão dos conceitos de Justiça e de trágico, que os gregos teorizam e representam de maneira exuberante nos palcos atenienses perante uma multidão ávida por purgar as paixões desenfreadas e para alcançar o equilíbrio necessário através da reconciliação com a deusa da Justiça.

Constata-se que uma articulação do direito e da filosofia com a literatura, as artes e a cultura, amplia o espectro interpretativo e possibilita captar todo um manancial de significações que subjazem ao arcabouço conceitual formulado, o que nem sempre vem à tona se o estudo seguir um rigor metodológico estéril e neutralizador. A perspectiva interdisciplinar abre um campo fértil de investigação, superando o corte linear das pesquisas tradicionais no âmbito do direito.

Investigaram-se subsídios que pudessem explicar a gênese da tragédia e as primeiras formalizações sobre a Justiça. Neste sentido, os pré-socráticos, em particular Anaximandro, Heráclito e Parmênides, são porta-vozes de um pensar fundacional no que concerne à definição sobre o justo, mas, outrossim, exprimem uma visão trágica da existência, o que os habilita a serem considerados os primeiros teóricos da Justiça e dos elementos constitutivos

\footnotetext{
15 Convém transcrever a tradução francesa, acompanhada do texto original: "Parlons d'abord des lois; de l'usage qu'on en doit faire [en conseillant et déconseillant], en accusant et se défendant.Il est évident que, si la loi écrite est défavorable à notre cause, il faut avoir recours à la loi commune, à des raisons plus équitables et plus justes. Il faut dire que 'dans le meilleur esprit' signifie ne pas appliquer à la rigueur les lois écrites; que l'équitable demeure toujours et ne change jamais, non plus que la loi commune, laquelle est selon la nature, tandis que les lois écrites changent souvent; d'où les paroles prononcées dans l'Antigone de Sophocle; la jeune fille se défend en disant qu'elle a enseveli son frère contre la loi de Créon, mais point contre la loi non écrite:" (ARISTOTE, 1932, tome premier, livre I, 1375a, p. 136). Cf. KERFERD (1984, p. 113).
} 
do trágico. Na verdade, a contribuição dos pré-socráticos para a cristalização das noções matriciais a respeito da Justiça e do trágico vem sendo reabilitada nos tempos modernos como forma de recuperar as preciosas lições que esse pensamento lega para o patrimônio filosófico dos homens. Demonstra-se, assim, que as concepções de Justiça e do trágico, derivadas da investigação em torno da phýsis no pensamento dos pré-socráticos, apresentam elementos estruturais convergentes que autorizam uma abordagem interdisciplinar.

Por conseguinte, retornar aos gregos e, principalmente, iniciar uma trajetória de pesquisa do trágico e da justiça pelos pré-socráticos constitui uma etapa incontornável para uma melhor e decisiva elucidação do desafio de buscar as bases fundantes do nosso pensar. De posse desses ensinamentos preliminares, viabiliza-se uma aproximação com o universo da tragédia de forma mais incisiva, procurando captar a verdadeira essência do trágico como expressão máxima da Justiça. No esplendor da tragédia grega, geralmente situado no século V a.C., o teatro e o homem teórico ainda estão unidos de maneira indissolúvel, mormente aos pensadores pré-socráticos.

\section{BIBLIOGRAFIA}

ARISTOTE. Rhétorique. Texte établi et traduit par Médéric Dufour. Paris: Les Belles Lettres, 1932, tome premier, livre I. (Collection des Universités de France).

ARISTÓteles. Arte Retórica e Arte Poética. Tradução Antônio Pinto de Carvalho; introdução e notas Jean Voilquin e Jean Capelle; estudo introdutório Goffredo Telles Júnior. Rio de Janeiro: Tecnoprint, [s.d.].

. Ética a Nicômaco. Tradução Leonel Vallandro; Gerd Bornheim da versão

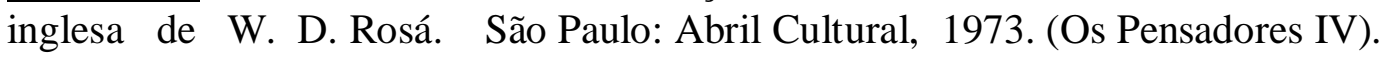

BARKER, Sir Ernest. Teoria política grega: Platão e seus predecessores. 2. ed. Tradução Sérgio Bath. Brasília: Editora Universidade de Brasília, 1978. (Coleção Pensamento Político, 2).

BORNHEIM, Gerd A. Breves observações sôbre o sentido e a evolução do trágico. In: sentido e a máscara. 2. ed. São Paulo: Perspectiva, 1969. (Coleção Debates).

(Org.). Os filósofos pré-socráticos. 7. ed. São Paulo: Cultrix, 1991.

BRUN, Jean. Os pré-socráticos. Tradução Armindo Rodrigues. Lisboa: Edições 70, 1991. (Biblioteca Básica de Filosofia).

DELEUZE, Gilles. Nietzsche e a filosofia. Tradução António M. Magalhães. Porto: RésEditora, [s.d.].

DETIENNE, Marcel. Os mestres da verdade na Grécia arcaica. Tradução Andréa Daher. Rio de Janeiro: Jorge Zahar, 1988. 
FINK, Eugen. A filosofia de Nietzsche. 2. ed. Tradução Joaquim Lourenço Duarte Peixoto. Lisboa: Editorial Presença, 1988.

GAGARIN, Michael. Dike in Archaic Greek Thought. In: Classical Philology. Chicago, Ill.: The University of Chicago, n.69: p.186-97, 1974.

GIRARD, René. A violência e o sagrado. Tradução Martha Conceição Gambini; revisão técnica Edgard de Assis Carvalho. São Paulo: Paz e Terra- UNESP, 1990.

GORGIA. Elogio di Elena. In: I sofisti: frammenti e testimonianze, I sofisti. Traduzione prefazione e note Maria Timpanaro Cardini. Bari: Gius Laterza \& Figli, p.56-60, 1923.

GUTHRIE, W.K.C. Os filósofos gregos de Tales a Aristóteles. Tradução Maria José Vaz Pinto. Lisboa: Editorial Presença, 1987.

HAVELOCK, Eric Alfred. The Greek concept of justice: from its shadow in Homer to its substance in Plato. Cambridge - London: Harvard University Press, 1978.

HEIDEGGER, Martin. Introdução à metafísica. 3. ed. Tradução, apresentação e notas Emmanuel Carneiro Leão. Rio de Janeiro: Tempo Brasileiro, 1987. (Biblioteca Tempo Universitário, 1).

HESÍODO. Os trabalhos e os dias. (Primeira Parte). 3. ed. Tradução, introdução e comentários Mary de Camargo Neves Lafer. São Paulo: Iluminuras, 1996. (Biblioteca Pólen).

HÖLDERLIN, Friedrich. Reflexões; seguidas de Hölderlin, tragédia e modernidade por Françoise Dastur. Tradução Márcia de Sá Cavalcante; Antonio Abranches. Rio de Janeiro: Relume-Dumará, 1994.

JAEGER, Werner Wilhelm. Paidéia: a formação do homem grego. 2. ed. Tradução Artur M. Parreira; adaptação do texto para edição brasileira Mônica Stahel M. da Silva; revisão do texto grego Gilson César Cardoso de Souza. São Paulo - Brasília: Martins Fontes Editora Universidade de Brasília, 1989.

KERFERD, George Briscoe. The sophistic movement. Cambridge - New York Melbourne: Cambridge University Press, 1984.

LAÊRTIOS, Diôgenes. Vidas e doutrinas dos filósofos ilustres. 2. ed. Tradução do grego, introdução e notas Mário da Gama Kury. Brasília: Editora Universidade de Brasília, 1977.

MONDOLFO, Rodolfo. O génio helénico. In: MAGALHÃES VILHENA, Vasco de. Panorama do pensamento filosófico. Tradução André Varga. Lisboa: Edições Cosmos, p.11-74, 1958, v. II.

O pensamento antigo: história da filosofia greco-romana. 3. ed. Tradução Lycurgo Gomes da Motta. São Paulo: Mestre Jou - Editora Universidade de São Paulo, 1971, v.I.

NIETZSCHE, Friedrich Wilhelm. O nascimento da tragédia ou helenismo e pessimismo. Tradução, notas e posfácio J. Guinsburg. São Paulo: Companhia das Letras, 1992. (Coleção Das Obras De Nietzsche). 
PLATÃO. Filebo. In: Diálogos de Platão: Parmênides - Filebo. Tradução Carlos Alberto Nunes. Belém: Universidade Federal do Pará, p.103-81, 1974, v. VIII. (Coleção Amazônica/ Série Farias Brito).

. Górgias ou A Oratória. 3. ed. Tradução, apresentação e notas Jaime Bruna. Rio de Janeiro: Bertrand Brasil, 1989.

REINHARDT, Karl. Sophocle. Traduit et préfacé par Emmanuel Martineau. Paris: Les Éditions de Minuit, 1994. (“Arguments”).

SNELL, Bruno. Las fuentes del pensamiento europeo: estudios sobre el descubrimiento de los valores espirituales de occidente en la antigua Grecia. Traducción Jose Vives. Madrid: Editorial Razón y Fe, 1965. (Colección "Formas del Espiritu").

SÓFOCLES. Antígone. In: Três tragédias gregas: Antígone, Prometeu prisioneiro, Ájax. Tradução Guilherme de Almeida. São Paulo: Perspectiva, 1997. (Signos; v.22).

Édipo Rei. In: A trilogia tebana: Édipo Rei, Édipo em Colono, Antígona. 2. ed. Tradução, introdução e notas Mário da Gama Kury. Rio de Janeiro: Jorge Zahar, p.20-96, 1991.

SOUSA, Eudoro. Fontes da história da filosofia antiga: textos traduzidos do grego por Eudoro de Sousa. In: Revista Brasileira de Filosofia. São Paulo: Instituto Brasileiro de Filosofia, 1954, v. IV, fascículos 1 (Janeiro - Março) e 2 (Abril - Junho). Fasc. 1: p. 96-123. Fasc. 2: p. 290-323.

SOUZA, José Cavalvante de. Os pré-socráticos: fragmentos, doxografia e comentários. Tradução José Cavalvante de Souza et al. São Paulo: Nova Cultural: p. 35-8, 1996 . (Os Pensadores).

VERNANT, Jean-Pierre. A tragédia grega: problemas de interpretação. In: MACKSEY, Richard; DONATO, Eugenio (Orgs.). A controvérsia estruturalista: as linguagens da crítica e as ciências do homem. Tradução Carlos Alberto Vogt; Clarice Sabóia Madureira. São Paulo: Cultrix: p.285-306, 1976.

VERNANT, Jean-Pierre. As origens do pensamento grego. 2. ed. corrigida. Tradução Ísis Borges B. da Fonseca. Rio de Janeiro - São Paulo: Difel, 1977.

VERNANT, Jean-Pierre; VIDAL-NAQUET, Pierre. Mito e tragédia na Grécia antiga. Tradução Anna Lia A. de Almeida Prado; Maria da Conceição M. Cavalcante; Filomena Yoshie Hirata Garcia. São Paulo: Duas Cidades, 1977.

WINDELBAND, Wilhelm. Alvores do pensamento filosófico grego: período cosmológico. In: MAGALHÃES VILHENA, Vasco de. Panorama do pensamento filosófico. Tradução Liselotte Rodrigues; Hermann Pflüger. Lisboa: Edições Cosmos: p.110-89, 1958, v. II.

Historia de la filosofía antigua. Traducción J. Rovira Armengol. Buenos Aires: Editorial Nova, 1955. (Coleccion La Vida del Espiritu).

ZELLER, Eduard. Outlines of the history of Greek philosophy. 13. ed. Translation L. R. Palmer; revision Dr. Wilhelm Nestle. New York: Dover, 1980. 